\section{Dating and correlating the French Mousterian}

SIR-We note the thermoluminescence dates from Le Moustier ${ }^{1}$ with interest and consider them to be valid and informative in the context of that site. However, it is regrettable that in his News and Views piece Paul Mellars ${ }^{2}$ has used the publication of these dates as an opportunity to reinterpret the chronostratigraphy of Combe Grenal and, by inference, the early Upper Pleistocene sequence of southwest France.

Mellars claims that various lines of chronostratigraphic evidence from "key sites" such as Le Moustier and Combe Grenal now converge to suggest that the Mousterian archaeological sequences are successive rather than parallel. Unfortunately, this claim is based on the contentious assumption that data from certain so-called "key" sequences can be simply used to interpret other sites, it omits relevant evidence and it balances perilously on the unjustified correlation of the oxygen isotope record from deep sea core V19-30 with arboreal pollen from Combe Grenal. The correlations suggested by Mellars fail to take into account a conventional radiocarbon date and thermoluminescence dates for Combe Grenal ${ }^{3}$ and ignore significant stratigraphic nonsequences between layers $55-56$ and 3536 at Combe Grenal and H1 and G4 at Le Moustier. The proposed correlation between the sites would imply an average error of 50 per cent in the available thermoluminescence dates. Although it is clear that the chronostratigraphic interpretation of the Combe Grenal data is not straightforward ${ }^{3}$, an error of this magnitude seems most unlikely (S.G.E. Bowman, personal communication). Indeed, the dates tend to support the alternative hypothesis of considerable overlap between the Le Moustier and Combe Grenal sequences as suggested by Bordes ${ }^{4}$ and Laville $^{5,6}$.

As an alternative to the thermoluminescence dates, Mellars compares arboreal pollen data from Combe Grenal with the oxygen isotope sequence. This correlation is problematic in the absence of independent dating to indicate the chronological position and duration of the pollen sequence. Without such dating the comparison of curves that represent ice volume and percentage of arboreal pollen rather than actual temperature is speculative, especially as the latter may vary due to local conditions and taphonomic factors as well as climatic change $e^{7,8}$.

Mellars uses the correlations in his two figures to support his particular view' of the succession of archaeological industries from Ferrassie to Quina and then Mousterian of Acheulian Tradition. This view would seem to be supported by his posi- tioning of the La Ferrassie hominid from Peyrony's layer $\mathrm{D}^{10,11}$ at $60,000-75,000 \mathrm{BP}$. This is surprising because it requires a hiatus in the order of $30,000-40,000$ years between layers $D$ and $E$, assuming the generally accepted dating of 30,000 35,000 BP for the Lower Perigordian archaeological assemblage in layer $\mathrm{E}$. Further, it does not allow for the possibility that the burials were inserted into layer $\mathrm{D}$ and could postdate both the deposits and, in Mellars view, the Ferrassie assemblage. Elsewhere ${ }^{11}$ the burials have been said to be late Mousterian, dating from Würm II at around 37,000 BP. On the evidence available it would seem unwise to try to arrange the fossil hominid record in line with the model given by Mellars.

Overall, the viewpoint presented seems premature and needs to be considered further in the context of a detailed review of the chronostratigraphic and archaeological evidence. Otherwise, to paraphrase Bordes $^{12}$ on the subject, we remain at risk of setting Charlemagne on a motorcycle.

Nick Ashton

JILL COOK

\section{Department of Prehistoric}

and Romano-British Antiquities,

\section{The British Museum,}

\section{London WC1B $3 D G, U K$}

1. Valladas, H., Geneste, J.M., Joron, J.L. \& Chadelle, J.P. Nature 322, 452 (1986)

Mellars, P. Nature 322, 410 (1986)

3. Bowman, S.G.E. \& Sieveking, G.de G. Pact 9,253 (1983).

4. Bordes, F. A Tale of Two Caves (Harper \& Row, New York, 1972).

5. Laville, H. World Archaeol. 4, 323 (1973)

6. Laville, H., Rigaud, J-P. \& Sackett, J.R. Rockshelters of the Perigord: Geological Stratigraphy and Archaeological the Perigord: Geological Stratigraphy and

7. Woillard, G.M. Nature 281, 558 (1979).

8. Turner, C. in Palynologie Arthéologique (eds RenaultMiskovsky, J., Bui-Thi, M. \& Girard, M.) 347 (CNRS, Paris. 1984).

9. Mellars, P. Proc. Prehist. Soc. 35, 134 (1969)

10. Capitan, L. \& Peyrony, D. Rev. Archéol. 22, 29 (1912).

11. Delporte, H. (ed.) Le Grand Abri de la Ferrassie (Institut de Paléontologie Humaine, Paris, 1984).

12. Bordes, F. Bull. Soc. Préhist. Francaise 78, 77 (1981).

Mellars Replies-First, I was well aware of the small series of thermoluminescence dates (6 against the 34 for Le Moustier) produced by the British Museum laboratory for the Combe Grenal sequence ${ }^{1}$, but these have little if any direct bearing on the central issues. The laboratory itself has already expressed serious reservations over the interpretation of several of these dates ${ }^{1}$ and drawn attention to the obvious conflict between the two dates of 105,000 and 113,000 years obtained for the basal levels of the sequence and the totality of the geological, palaeobotanical, faunal and archaeological evidence which points to a minimum age for these deposits in the region of $130,000-140,000 \mathrm{BP}(=$ ocean core stage 6 , or 'Rissian' in the French terminology) ${ }^{1-3}$ Dating of a parallel series of samples by the same laboratory from the nearby site of Pech de l'Azé IV has been dismissed by the laboratory as "too young to be

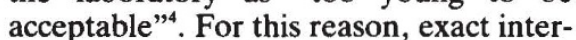

pretation of the Combe Grenal sequence on the basis of the thermoluminescence dates alone would clearly be hazardous.

What is significant is that 5 of the 6 thermoluminescence dates for the Combe Grenal sequence are substantially earlier than any of the 34 dates for the Le Moustier succession - which is fully consistent with the general conclusion that the greater part of the geological and archaeological sequence at Combe Grenal is entirely earlier than that at Le Moustier. Note that dating of a sample from the upper (but not final) Mousterian levels at Pech de l'Azé IV yielded a date of $19,600 \pm 1,600 \mathrm{BP}$, which is approximately half of the known age of these levels, and demonstrably in error by a factor of at least ten standard deviations on the measured sample age ${ }^{4}$.

Second, I am not quite sure I understand the objections to the proposed correlation between the Combe Grenal sequence and the oxygen isotope record in ocean cores, which is based not on my own interpretations but on the correlations already adopted by Laville and others for the major part of the Combe Grenal succession $^{5,6}$. The interpretation of the ocean core sequence as a record of climatic fluctuations depends not only on the record of oxygen isotope ratios but also on studies of faunal assemblages in ocean core sediments (as a reflection of seasurface temperatures) ${ }^{7}$ and on the close correlations now established with palaeobotanical records from terrestrial and offshore sites, particularly the long and well-dated pollen sequence from Grande Pile in north-eastern France ${ }^{8,9}$. Similarly, the interpretation of the climatic sequence at Combe Grenal depends not only on changing arboreal pollen ratios (though these are the easiest to illustrate in simple graphical form) but on the parallel and mutually consistent records of geology, sedimentology and faunal assemblages ${ }^{2,3,10}$. The remarkable similarity in all these independent records of climatic change can hardly be dismissed by a passing reference to "local and taphonomic factors" and provides unambiguous support for the climatological chronological correlations proposed by myself, Laville ${ }^{5}$, Dennell ${ }^{6}$ and others for the Combe Grenal succession.

Third, limited depositional hiatuses should perhaps have been indicated in figures 1 and 2 of my article between layers $\mathrm{G}$ and $\mathrm{H}$ at Le Moustier and layers 35 and 36 at Combe Grenal - but these episodes have no bearing on the specific correlations proposed between the two sites.

Fourth, I fully accept the implications of a major hiatus between the Mousterian and Upper Palaeolithic levels at La Ferrassie. Similar depositional/erosional hiatuses are well documented at several other cave and rock-shelter sites in southwest France, for example between the 